\title{
Specificity of Exemption from Punishment in the Field of Safety Rules Violation in Mining Operations
}

\author{
Valeriya Terentieva ${ }^{1, *}$, and Alexander Naumov ${ }^{1}$ \\ ${ }^{1}$ Kemerovo State University, 650000, 6 Krasnaya st., Kemerovo, Russia
}

\begin{abstract}
The article examines the problem of the courts' application of exemption from punishment for criminal violations of the safety rules in mining operations. The application practice of exemption from punishment by courts in this category of cases is analyzed. On the basis of the data the authors drew the conclusions about the frequency and chosen measures of application of exemption from punishment. The general features of cases in which exemption from punishment was applied are described, and the personality characteristic of a criminal accused of criminal violations of safety rules in mining operations are considered.
\end{abstract}

\section{Introduction}

In accordance with Part 3 of Art. 37 of the Constitution of the Russian Federation, everyone has the right to work in conditions that meet the requirements of safety and hygiene ... [1]. Safety violations in mining industry are one of the most dangerous acts with serious consequences, often with a large number of victims. In the literature, the causes, number, dynamics and other indicators of accidents in mines and open pits have been investigated repeatedly [2]. It has been proven that mortality at mining enterprises is an inevitable value that is actually included in the cost of extracted resources [3]. Nevertheless, a number of aspects of these crimes remains unstudied. One of these aspects is exemption from punishment for these crimes.

\section{Materials and Methods}

The regulatory framework for this study is the Criminal Code of the Russian Federation (hereinafter - the CC RF).

Crimes in the field of violation of work safety rules are provided in the following articles of the Criminal Code of the Russian Federation:

- Art. 143 of the Criminal Code of the Russian Federation, which provides liability for violation of labor protection requirements committed by a person who is entrusted with obligations to comply with them;

*Corresponding author: terent@list.ru 
- Art. 216 of the Criminal Code of the Russian Federation, which provides liability for violation of safety rules during construction or other work;

- Art. 217 of the Criminal Code of the Russian Federation, which provides liability for violation of industrial safety requirements for hazardous production facilities [4].

We considered the problems of qualifying criminal violations of safety rules during mining in previous research [5], therefore, we are not intended to discuss this issue in detail, but the basic rules for qualifying these crimes will be briefly presented in the third section of the article.

The empirical basis of the study is a selection of court sentences in criminal cases for crimes under Art. 143, 216, 217 of the Criminal Code of the Russian Federation. The empirical base of the study includes court sentences provided that they comply with the following conditions:

- the person (s) were convicted under one of the following articles of the Criminal Code of the Russian Federation - 143, 216, 217;

- the crime scene is a mining enterprise - a mine or open pit;

- a judicial act is a verdict of a court of first instance, or a higher instance, provided that it indicates at least briefly the factual circumstances of the case;

- the judicial act was issued within the last 5 years for the period from 2016 to 2020.

Based on the above criteria, we selected 74 court verdicts. Since the crimes under consideration are not common, we consider this number to be sufficient to consider it as a representative sample.

The methodology of working on the article includes both an analysis of Russian legislation and comparative studies using correspondence analysis $[6,7]$.

\section{Results and Discussion}

In accordance with clause 5 of the Resolution of Plenum of the Supreme Court of the Russian Federation "On judicial practice in criminal cases on violations of labor protection requirements, safety rules during construction or other work, or industrial safety requirements of hazardous production facilities" "when resolving the issue of classifying a certain production such as hazardous production facilities in a criminal case on a crime under Article 217 of the Criminal Code of the Russian Federation, the courts should be guided by the federal law of July 21, 1997 No. 116-FL "On industrial safety of hazardous production facilities." In particular, the category of hazardous production facilities includes facilities where ... mining operations are carried out (except for the extraction of widespread minerals and the development of alluvial deposits of minerals, carried out in an open way without the use of blasting operations) ... "[8]. The above position of the Supreme Court of the Russian Federation is based on the exclusion of mining from the disposition of Art. 216 of the Criminal Code of the Russian Federation, in which the indication of mining operations as a crime scene took place in the previous edition.

Thus, the Supreme Court in its clarification directly points to the need to qualify violations of safety rules when conducting mining operations under Art. 217 of the Criminal Code of the Russian Federation, not Art. 216 of the Criminal Code of the Russian Federation, as it was before.

Nevertheless, as the analysis of judicial practice has shown, the courts still issue sentences under Art. 216 of the Criminal Code of the Russian Federation, which creates uncertainty in law enforcement, since many sentences contain a conviction specifically under Art. 217 of the Criminal Code of the Russian Federation. It should also be borne in mind that the above Resolution of Plenum of the Supreme Court of the Russian Federation was published on November 29, 2018, and the change in the disposition of Art. 216 of the Criminal Code of the Russian Federation was introduced on April 23, 2018, therefore the 
need to analyze sentences as under Art. 216, and under Art. 217 of the Criminal Code of the Russian Federation is beyond doubt. In addition, we analyzed court sentences under Art. 143 of the Criminal Code of the Russian Federation, which is a contiguous corpus delicti in relation to Art. 216 and 217 of the Criminal Code of the Russian Federation, which differ in object, subject, nature of the rules violated and, in part, in consequence.

We conducted a quantitative analysis of the judicial qualification of crimes against the safety rules in mining operations, the results of which are presented in the table below.

Table 1. Number of court sentences for crimes against mine safety rules

\begin{tabular}{|c|c|c|c|c|c|c|}
\hline & $\mathbf{2 0 1 6}$ & $\mathbf{2 0 1 7}$ & $\mathbf{2 0 1 8}$ & $\mathbf{2 0 1 9}$ & $\mathbf{2 0 2 0}$ & Total \\
\hline Art. $143 \mathrm{CC}$ & 0 & 0 & 0 & 0 & 2 & 2 \\
\hline Art. 216 CC & 0 & 18 & 20 & 11 & 3 & 53 \\
\hline Art. 217 CC & 1 & 0 & 2 & 9 & 7 & 19 \\
\hline Absolvent & 0 & 0 & 1 & 0 & 0 & 1 \\
\hline Total & 1 & 18 & 23 & 20 & 12 & 74 \\
\hline
\end{tabular}

Based on the above data, we conclude the following:

- The courts began to qualify violations of the safety rules in mining operations under Art. 217 of the Criminal Code of the Russian Federation after the new Resolution of Plenum of the Supreme Court of the Russian Federation.

- The courts did not immediately begin to apply the new qualification rules, however, gradually the proportion of sentences under Art. 217 of the Criminal Code of the Russian Federation in relation to the proportion of sentences under Art. 216 of the Criminal Code of the Russian Federation began to increase, and in 2020, it surpassed it.

- There is a sharp decrease in the number of sentences in 2020, which, in our opinion, is caused by the epidemic of coronavirus infection.

- An inexplicably small number of sentences in 2016 (only 1).

- Extremely small number of sentences declared not guilty (only 1 out of 74).

- An extremely small number of sentences under Art. 143 of the Criminal Code of the Russian Federation ( 2 in total).

Table 1. Penal criminal law sanction assigned to a person

\begin{tabular}{|c|c|c|c|c|}
\hline & Art. 143 & Art. 216 & Art. 217 & Total \\
\hline Probation & 2 & 22 & 7 & 31 \\
\hline $\begin{array}{c}\text { Remission of penalty in connection } \\
\text { with the act of amnesty }\end{array}$ & 0 & 0 & 1 & 1 \\
\hline $\begin{array}{c}\text { Exemption from criminal liability: } \\
\text { a. judicial fine } \\
\text { b. reconciliation with the victim } \\
\text { c. expiration of the statute of }\end{array}$ & 0 & 12 & 5 & 17 \\
\hline
\end{tabular}




\begin{tabular}{|c|c|c|c|c|}
\hline limitations for criminal prosecution & & & & \\
\hline $\begin{array}{c}\text { Deprivation of freedom without } \\
\text { release from punishment }\end{array}$ & 0 & 3 & 5 & 8 \\
\hline Personal restrain & 0 & 5 & 0 & 5 \\
\hline Corrective labor & 0 & 1 & 1 & 2 \\
\hline Fine & 0 & 10 & 0 & 10 \\
\hline Total & 2 & 53 & 19 & 74 \\
\hline
\end{tabular}

Based on the above data, we conclude the following:

- Probation is the most frequently applied measure to persons who have committed a crime in the field of violation of work safety rules (31 sentences out of 74). Moreover, probation is actually the only basis for exemption from punishment for these crimes. A single application of exemption from punishment connected with the act of amnesty is rather an exception to this regularity.

- Exemption from criminal liability in the framework of studied cases manifested itself in different forms - a judicial fine, reconciliation with the victim, as well as the expiration of the statute of limitations for bringing a person to criminal responsibility - only 17 sentences out of 74 .

- The convicted was sentenced to real punishment only in 25 cases out of 74 , while imprisonment was assigned only in 8 cases. In the rest of the sentences, the court appointed a milder type of punishment. In addition, it is also evident that under Art. 217 of the Criminal Code of the Russian Federation, the court prescribes mainly imprisonment (5 cases out of 6), and under Art. 216 of the Criminal Code of the Russian Federation, the courts are more inclined towards the appointment of a fine as a type of punishment (10 cases out of 19).

Since our study is devoted to the issues of exemption from punishment, we will dwell in more detail on the application of this legal institution by the courts.

The legal scholars continually addressed the general problems of probation. In short, some of them consider probation as one of the grounds for exemption from punishment [9], and others as an independent form of criminal responsibility implementation, an institution of a special kind [10]. We adhere to the point of view that probation is one of the grounds for exemption from punishment; therefore, we included its application by the courts in the subject of our research.

Based on the analysis of studied sentences, we identified the following general features of cases in which a probation was applied by the court (these circumstances were encountered in all or most of these cases):

- the crime was committed by one person. Although the considering crimes are imprudent, in connection with which their commission in complicity is impossible, nevertheless, imprudent concurrence is actually considered by the courts as a circumstance that does not allow the release of persons from punishment. As a rule, the law does not affect employers; rather, it focuses on mine managers in determining responsibility for the safety and health of miners [11].

Nevertheless, in a number of cases, even when a crime was committed by two persons, the court still applied a probation. So, by the verdict of the Uchalkinsky District Court of the Republic of Bashkortostan dated 03/07/2019, case number 1-8 / 2019 (1-246 / 2018) L.I.Y. and A.A. were found guilty of committing a crime under Part 2 of Art. 216 of the Criminal Code of the Russian Federation. L.I.Y. was sentenced to 2 years in prison and 
A.A. to 1 year in prison. The court ordered to be conditional the punishment for L.I.Y. and A.A. with a probationary period 2 years for L.I.Y. and 1 year for A.A. The court took into account the following mitigating circumstances: positive characterizing data, bringing to criminal responsibility for the first time, serious violation of safety rules when working at height by the deceased T.S.V.; A.A. had a dependent minor child (at the time of the crime), advanced age L.I.Y. The court has not established aggravating circumstances in relation to the defendants. As the personality data, the court takes into account that the defendants are married, were not registered with the psychiatrist and narcologist, and were not previously involved in criminal and administrative responsibility, are positively characterized by their place of residence and work [12];

- the convicted person has no criminal record. In our opinion, this circumstance is due to the fact that managers prefer not to hire persons with a criminal record, as well as the fact that violations of work safety rules are committed by persons generally undisposed to committing crimes. Nevertheless, among the cases considered in one of them, the defendant had a criminal record by the time the sentence was imposed, which did not prevent the court from a probation. Thus, by the verdict of the Prokopyevskiy District Court of the Kemerovo Region dated January 16, 2018 in case number 1-28 / 2018 (1-193 /17), the defendant S.S.M. 08/10/2017 by the verdict of the magistrate of the judicial district N 4 of the Kiselevsky city judicial district of the Kemerovo region under Art. 264.1 of the Criminal Code of the Russian Federation, a punishment was imposed in the form of 100 hours of compulsory work with an additional punishment prohibiting to be engaged in activities related to driving vehicles for a period of 1 year. The main punishment in the form of compulsory work was on September 29, 2017, an unserved term of additional punishment in the form of prohibition to be engaged in activities related to driving vehicles was at the time of sentencing 7 months 6 days. S.S.M. found guilty of committing a crime under Part 2 of Art. $216 \mathrm{CC}$ RF, and he was sentenced to 1 (one) year 6 (six) months in prison. The final punishment of S.S.M. appointed in the form of 1 (one) year 6 (six) months of imprisonment, with the deprivation of the right to be engaged in activities related to driving vehicles for a period of 7 (seven) months 6 (six) days. The imposed sentence in the form of imprisonment was decided to be considered conditional with a probationary period of 1 (one) year [13].

- a person has committed a violation of the safety rules for mining operations, provided by the main Part 1 of Art. 143, 216 or 217 of the Criminal Code of the Russian Federation. In cases where the court qualified the act under Part 2 or Part 3 of Art. 216 or 217 of the Criminal Code of the Russian Federation, then it applied real punishment, but qualifications even under Part 3 of Art. 216 or 217 of the Criminal Code of the Russian Federation is not always an obstacle to the application of a probation. Thus, by the verdict of the Norilsk City Court of the Krasnoyarsk Territory dated January 15, 2019 case number 1-10 / 2019 T.A. and T.Y. were found guilty of committing a crime under Part 3 of Article 217 of the Criminal Code of the Russian Federation. They were sentenced to imprisonment - T.A. for a period of 2 (two) years; T.Y. for a period of 3 (three) years. The punishment for T.A. and T.Y. in the form of imprisonment, in accordance with the provisions of Art. 73 of the Criminal Code of the Russian Federation, it was decided to be considered conditional with a probationary period of 2 (two) years. According to Parts 1, 2 Art. 61 of the Criminal Code of the Russian Federation, as circumstances mitigating the punishment of the defendants, the court takes into account the defendants' long employment history, rewards for performance, age, state of health, taking into account the existing chronic diseases, confirmed by medical documents. T.A. expressed remorse for the deeds, assisted in establishing the circumstances of the case, which is generally regarded by the court as an active contribution to the investigation of the crime. T.Y. had a young child [14].

- the obligatory presence of mitigating evidences; 
- the absence of aggravating evidences.

The most common mitigating evidences are:

- positive characteristics at the place of work and place of residence;

- committing a crime for the first time;

- the presence of dependent minor children or disabled parents;

- the confession of guilt by the defendant and his remorse for what he did.

In addition to the above, there are also some other mitigating circumstances:

- advanced age of the convict;

- the recent death of close relatives of the convict;

- active contribution to the disclosure and investigation of the crime;

- violation of safety rules by the victim himself;

- long employment history;

- the presence of chronic diseases, etc.

In general, the persons to whom a probation is applied for crimes in the field of violation of mining safety rules have the following criminological characteristics. It is a man of an adult (including an elderly) age who has dependent minor children (less often disabled parents), is not convicted (only in 2 sentences the perpetrator had a conviction for a crime of minor offence), is characterized positively in the family and at work. It can be unambiguously argued that those responsible for these crimes belong to the random type of personality of criminals, that is, they commit crimes for the first time as a result of a coincidence of circumstances with a general socially positive personality.

\section{Conclusion}

Summing up the conducted research, we come to the following conclusions:

1. The courts qualify violations of the safety rules in mining operations under 3 articles: Art. 143, 216 and 217 of the Criminal Code of the Russian Federation. At the same time, the proportion of sentences under Art. 217 of the Criminal Code of the Russian Federation in relation to the proportion of sentences under Art. 216 of the Criminal Code of the Russian Federation has been increasing over the past years, and in 2020, it surpassed it.

2. The most frequently applied to persons who have committed a crime in the field of violation of the safety rules at work is a probation. The probation is also the only basis for exemption from punishment for these crimes.

3. The peculiarities of the defendants in cases of criminal violations of safety rules in production work are - the guilty person alone commits the crime, as a rule; the guilty person has no criminal record; the crime is classified under Part 1 or Part 2 of Art. 143, Art. 216 or 217 of the Criminal Code of the Russian Federation. However, the conviction under Part 3 of these articles does not preclude the application of probation.

\section{References}

1. The Constitution of the Russian Federation (adopted by a popular vote on 12.12.1993 with amendments approved during a nationwide vote on 01.07.2020).

2. E.A. Khamidullina, S.S. Timofeeva, G.I. Smirnov, IOP Conf. Ser.: Mater. Sci. Eng. 262, 012210 (2017)

3. T.V. Newhouse, Coal mine safety (BMS, Manchester, 2009)

4. The Criminal Code of the Russian Federation, Collection on Laws of Russian Federation, 25, 2954 (1996)

5. M. Agienko, A. Naumov, I. Gaag, Yu. Volgin, E3S Web Conf. 41, 04046 (2018) 
6. G.Q. Mu, China Mining Magazine, 12, 44-47 (2009)

7. J. Maiti, Singh A., S. Mandal, V. Abhishek, Safety Science, 68, 24-33 (2014)

8. Resolution of the Plenum of the Supreme Court of the Russian Federation Resolution of the Plenum of the Supreme Court of the Russian Federation dated November 29, 2018 No. 41 "On judicial practice in criminal cases on violations of labor protection requirements, safety rules during construction or other work, or industrial safety requirements of hazardous production facilities" (Supreme Courts of the Russian Federation, Moscow, 2019)

9. O.V. Filippova, S.M. Kurbatova, Ju.V. Andreeva, EurAsian Journal of BioSciences ,14(2), 6991-6996 (2020)

10. G.V. Abschilava, A.A. Gorshenin, O.A. Maximov, Opcion, 34(85), 1565-1586 (2018)

11. A. Doran, J. Nat. Res. Env. Law, 11, 1 (1996)

12. Verdict of the Uchalinsky District Court of the Republic of Bashkortostan dated 03/07/2019 in case No. 1-8 / 2019

13. The verdict of the Prokopyevsky District Court of the Kemerovo Region dated January 16, 2018 in case No. 1-28/2018

14. Verdict of the Norilsk City Court of the Krasnoyarsk Territory dated 15.01.2019 No. 1$10 / 2019$ 